\title{
Assessment of Parenting Practices and Styles and Adolescent Sexual Behavior among High School Adolescents in Addis Ababa, Ethiopia
} Amsale Cherie ${ }^{1 *}$ and Yemane Berhanie ${ }^{2}$

${ }^{1}$ Department of Nursing and Midwifery, Addis Ababa University, Ethopia

${ }^{2}$ Addis Continental Institute of Public Health, Ethiopia

\begin{abstract}
Background: Healthy sexuality is a developmental process which needs investments from parents. Nonetheless, little is known about the effect of parenting practices and styles on the sexual risk behavior of young people.

Objectives: to assess the effect of different parenting styles and parenting practices on the sexual behavior of adolescents.

Methods: A cross-sectional study was conducted among 3840 randomly selected high school adolescents using three stage sampling in Addis Ababa, Ethiopia. Data were collected by a self-administered anonymous pre tested questionnaire. Logistic regression analysis was done to identify parental factors associated with sexual behavior.

Results: From the 3543 students participated in this study $723(20.4 \%)$ respondents reported ever having sexual intercourse and nearly three -quarter of those who initiated sex were involved in risky sexual practices. Respondents who live with both parents [AOR= $0.48(95 \% \mathrm{Cl}: 0.21-0.83)]$ and perceived connected to their parents $[\mathrm{AOR}=0.51(95 \% \mathrm{Cl}: 0.22-0.96)]$ were less likely to experience risky sexual behavior. Similarly, students from authoritarian and authoritative parents were more likely to have safe sexual practices [AOR $=0.38(95 \% \mathrm{Cl}: 0.23-0.86)]$ and $[\mathrm{AOR}=0.41(95 \% \mathrm{Cl}: 0.24-0.93)]$ respectively compared to children from permissive parenting styles. In addition, parent child communication about sexual issues $[A O R=0.56(95 \% \mathrm{Cl}: 0.31-0.94)]$ and parental monitoring were protective from risky sexual behavior $[\mathrm{AOR}=0.52(95 \% \mathrm{Cl}: 0.32-0.92)]$
\end{abstract}

Conclusion: Appropriate parenting practices have a shielding effect from adolescent sexual risk behavior. Interventions that enable parents to build proper parenting practices, skills and styles have paramount importance.

Keywords: Adolescents; Parenting practices; Parenting style; Sexual behavior; HIV; STIs; Ethiopia

\section{Back Ground and Statement of the Problem}

Parents are the first socializing agents, teachers, leaders and counselors to their children. Parent's guidance and support is always important, however it is highly needed in the period of adolescence, which is a transition from childhood to adulthood and is characterized by spurts of physical, mental, emotional, social and sexual development [1]. Healthy sexuality is a developmental process which needs investments from parents.

Sexual risk taking which includes early coital debut, multiple sexual relation, non use and inconsistent use of condom is becoming common among substantial numbers of young people. Risky sexual activity puts adolescents at risk of various reproductive health challenges. It is identified that about 20,000 girls under the age of 18 give birth each day [2] nearly 60 percent of unsafe abortions in Africa occur among women aged less than 25 years [3] and about 100 million adolescents acquire curable sexually transmitted disease each year [4-7] and youth, ages 1524 , account for approximately $33 \%$ of new HIV infections [8].

Parenting style is defined as the ardent climate provided by parents and parenting practices signify the behaviors in which parents involve with the purpose of undertaking specific socialization goals. Research evidences showed that parental practices such as parent child connectedness, parental monitoring and parents and adolescents communication about sexuality is protective against risky sexual behavior [9-11]. Baumrind's identified four parenting styles: Authoritative, Authoritarian, Permissive and Neglectful. Studies showed that children from authoritative parents tend to engage in fewer risk behaviors than children from other parenting types [12,13].

Although, Adolescent's behavior is deeply affected by the family environment they live and parents are the main source of influence and credible sources to their children with regard to sexuality little is known in Ethiopia about the relationship between the different parenting practices and safe sexual behavior. Thus, it is the purpose of this study to assess the effect of different parenting styles and parenting practices on the sexual behavior of adolescents.

The result of this study will help to formulate policies, design strategies and programmes about proper parenting practices for the current and would be parents.

\section{Subjects and Methods}

This cross sectional study was conducted among regularly attending 15-24 years of age high school youth in Addis Ababa, the capital city of Ethiopia. Addis Ababa is administratively divided into 10 Sub Cities.

A sample size of 3840 students was calculated based on proportion of parenting practice $50 \%, 95 \%$ confidence interval, power $80 \%$, margin of error 0.03 , design effect of 3 and $20 \%$ allowance for non-response [14].

A three stages sampling was used to select study participants from the source population. In the first stage one high school was selected randomly from each sub-city. The sample size was assigned proportionate to the total student population for each selected school. One section was selected from each grade in the identified schools

*Corresponding author: Amsale Cherie, Department of Nursing and Midwifery, Addis Ababa University, P.O. Box: 33412, Addis Ababa, Ethiopia, Tel: 09-66-37-63; E-mail: amsalec2002@yahoo.com

Received December 02, 2014; Accepted January 28, 2015; Published February 09, 2015

Citation: Cherie A, Berhanie Y (2015) Assessment of Parenting Practices and Styles and Adolescent Sexual Behavior among High School Adolescents in Addis Ababa, Ethiopia. J AIDS Clin Res 6: 424. doi:10.4172/2155-6113.1000424

Copyright: ( 2015 Cherie A, et al. This is an open-access article distributed unde the terms of the Creative Commons Attribution License, which permits unrestricted use, distribution, and reproduction in any medium, provided the original author and source are credited. 
by lottery method. Using a systematic sampling method every third student from the selected section was taken until the allocated number was reached.

Data were collected using pretested anonymous self-administered questionnaire. The questionnaire was adapted from Youth Risk Behavior Survey [15]. The questionnaire was prepared in English and translated and administered in Amharic (the Ethiopian national language). The research team which consists of two supervisors (public health experts) and ten nurses (data collectors) were trained for 2 days to help them understand the purpose of the study and familiarize themselves with the questions. Scheduled and unscheduled visits during data collection and official contact with concerned personnel and institutions were made by the Principal Investigator. The questionnaire consisted of items dealing with the dependent variable risky sexual behavior of students and a composite score of parental factors: living arrangement, parent adolescent communication, parental monitoring, parental connectedness, and parenting style

\section{Parent-adolescent communication}

The questionnaire consisted of six items about parent-adolescent Communication. The students were asked whether they communicated with their parents about: sex, HIV, STIs, pregnancy, changes occurring during adolescents and about school. Communication between parents and adolescents on sexual and reproductive health was measured based on young people's perception that they have discussed about at least one sex and reproductive health-related topics with their parents in the past six months.

\section{Parental monitoring}

Respondents were asked five items: my parent(s) know where I am after school, my parent(s) know all my friends, I need permission from my parents to go anywhere, my parents allow me to stay at friend's house overnight if I want to, my parents do not mind if I get a boyfriend/ girlfriend". Parental monitoring was defined as participant's perception that their parents know their whereabouts, and associates.

\section{Parental connectedness and family relationship}

This was assessed by 9 items: family members ask each other for help, family members like to spend free time with each other, family members feel very close to each other, family members can easily think of things to do together as a family, family does things for fun together, listen to what other family members have to say, even when they disagree, will be available when others in the family want to talk to them, have meals together and conflict in the family. Parental connectedness is defined as those adolescents who responded "yes" to at least 5 parental connectedness questions.

\section{Parenting styles}

One item assessed the perception of students about parenting styles: they were asked about how decision was made in the home. The measure was: "how are the most important decisions made between you and your parent(s)?" The choice where: “They tell me exactly what to do" (authoritarian); "They ask my opinion but they have the final say" (authoritative); "They trust me to decide for myself" (permissive); "They don't care what I do, so I decide for myself" (neglectful).

\section{Sexual risk-taking}

Four items were used to determine the sexual risk-taking behaviors of the respondents. Students were asked: "Have you ever had sexual intercourse? At what age have you had sexual debut? During your life, with how many people have you had sexual intercourse? The last time you had sexual intercourse did you or your partner use a condom?"

Risky sexual behavior is defined as sexual debut before the age of 16 , had either unprotected sex or had multiple sexual partnership.

Data coding, entry, and cleaning was processed using EPI info version 6.4 and the analysis was made using SPSS version 15 statistical package. Variables with significant association in the bivariate analysis were entered in to logistic regression to estimate the odds and standard errors of having risky sexual behaviors. Variables with $\mathrm{P}$ value less than 0.05 was considered significant

Ethical clearance was secured from the Addis Ababa University, College of Health Sciences IRB. Verbal informed consent was obtained from each respondent after explaining the purpose of the study. Participants were assured that participation is voluntary, the information they provide will be kept completely anonymous and confidential. Students were also informed the possibility of opting out at any time if they feel to do so.

\section{Results}

Table 1 summarizes the sample characteristics of respondents. From the 3840 eligible in school adolescents 3543(92.5\%) fully participated in the study of these about half were females and 796(22.5\%) of students were in the age group 15 - 16 years. In addition, 1964(55.4\%) participants were living with both parents and 602(17.0\%) of student's fathers and 928(26.2\%) of students mothers were without formal education.

\section{Parental connectedness and family relationship}

As shown in table 2, 2038(57.5\%) students reported that their family members feel very close to each other and 1388(39.2\%) respondents indicated that their family members can easily think of things to do together as a family.

In addition, 1790(50.5\%) of the students said they listen to what other family members have to say, even when they disagree and $1072(30.3 \%)$ of the respondents have meal together with the family at least once per day.

Regarding conflict in the family, 1090(30.8\%) of the students pointed out that adults in their household fight.

\begin{tabular}{|l|c|}
\hline Variable & Number\% \\
\hline Sex & \\
Female & $1789(50.5)$ \\
Male & $1754(49.5)$ \\
\hline Age group (mean = 17.6, SD = 1.5 years) & \\
Young adolescents (15-16) & $796(22.5)$ \\
Older adolescents (17-24) & $2747(77.5)$ \\
\hline School Grade & \\
Ninth & $701(19.8$ \\
Tenth & $703(20.3)$ \\
Preparatory & $1770(21.7)$ \\
Preparatory & $11670(18.9)$ \\
Vocational & $699(19.7)$ \\
\hline Living arrangement & $1964(55.4)$ \\
Both Parents & $1579(44.6)$ \\
\hline Other arrangements & \\
\hline Paternal literacy & $602(17.0)$ \\
\hline Illiterate and Non formal & $2941(83.0)$ \\
\hline Formal school & \\
\hline Maternal literacy & $928(26.2)$ \\
\hline Illiterate and Non formal & $2615(73.8)$ \\
\hline Formal school & \\
\hline
\end{tabular}

Table 1: Socio-demographic Characteristics of 3543 High School Students in Addis Ababa, Ethiopia. 


\begin{tabular}{|c|c|}
\hline Variables & Number(\%) \\
\hline $\begin{array}{l}\text { Family members ask each other for help } \\
\text { 1. Yes } \\
\text { 2. No }\end{array}$ & $\begin{array}{l}\text { 1712(48.3) } \\
1831(51.7)\end{array}$ \\
\hline $\begin{array}{l}\text { Family members like to spend free time with each other } \\
\text { 1. Yes } \\
\text { 2. No }\end{array}$ & $\begin{array}{l}1498(42.3) \\
2045(57.7)\end{array}$ \\
\hline $\begin{array}{l}\text { Family members feel very close to each other } \\
\text { 1. Yes } \\
\text { 2. No }\end{array}$ & $\begin{array}{l}2038(57.5) \\
1505(42.5)\end{array}$ \\
\hline $\begin{array}{l}\text { We can easily think of things to do together as a family } \\
\text { 1. Yes } \\
\text { 2. No }\end{array}$ & $\begin{array}{l}1388(39.2) \\
2155(60.8)\end{array}$ \\
\hline $\begin{array}{l}\text { I listen to what other family members have to say, even when } \\
\text { I disagree. } \\
\text { 1. Yes } \\
\text { 2. No }\end{array}$ & $\begin{array}{l}1790(50.5) \\
1753(49.5)\end{array}$ \\
\hline $\begin{array}{l}\text { I am available when others in the family want to talk to me. } \\
\text { 1. Yes } \\
\text { 2. No }\end{array}$ & $\begin{array}{l}2144(60.5) \\
1399(39.4)\end{array}$ \\
\hline $\begin{array}{l}\text { My family does things for fun together } \\
\text { 1. Yes } \\
\text { 2. No }\end{array}$ & $\begin{array}{l}914(25.8) \\
2629(74.2)\end{array}$ \\
\hline $\begin{array}{l}\text { The adults in my household fight } \\
\text { 1. Yes } \\
\text { 2. No }\end{array}$ & $\begin{array}{l}1090(30.8) \\
2453(69.2)\end{array}$ \\
\hline $\begin{array}{l}\text { The children in my household fight } \\
\text { 1. Yes } \\
\text { 2. No }\end{array}$ & $\begin{array}{l}458(12.9) \\
3085(87.1)\end{array}$ \\
\hline $\begin{array}{l}\text { Family members eat meal together at least } \\
\text { 1. Yes } \\
\text { 2. No }\end{array}$ & $\begin{array}{l}1072(30.3) \\
2471(69.7)\end{array}$ \\
\hline
\end{tabular}

Table 2: Parental connectedness and family relationship among high schoo students in Addis Ababa.

\begin{tabular}{|c|c|}
\hline Variables & Number(\%) \\
\hline $\begin{array}{l}\text { My parent(s) /guardians talk to me about sex } \\
\text { 1. Yes } \\
\text { 2. No }\end{array}$ & $\begin{array}{l}674(19.0) \\
2869(81.0)\end{array}$ \\
\hline $\begin{array}{l}\text { My parent(s) /guardians talk to me about HIV } \\
\text { 1. Yes } \\
\text { 2. No }\end{array}$ & $\begin{array}{l}748(21.1) \\
2795(78.2)\end{array}$ \\
\hline $\begin{array}{l}\text { My parent(s) /guardians talk to me about sexually transmitted } \\
\text { diseases } \\
1 \text {. Yes } \\
\text { 2. No }\end{array}$ & $\begin{array}{l}554(15.6) \\
2989(84.4)\end{array}$ \\
\hline $\begin{array}{l}\text { My parent(s) /guardians talk to me about pregnancy } \\
\text { 1. Yes } \\
\text { 2. No }\end{array}$ & $\begin{array}{l}712(20.1) \\
2831(79.9)\end{array}$ \\
\hline $\begin{array}{l}\text { My parent(s) /guardians talk to me about the changes } \\
\text { occurring during adolescence } \\
\text { 1. Yes } \\
\text { 2. No }\end{array}$ & $\begin{array}{l}1012(28.6) \\
2531(71.4)\end{array}$ \\
\hline $\begin{array}{l}\text { My parent(s)/guardians talk to me about school } \\
\text { 1. Yes } \\
\text { 2. No }\end{array}$ & $\begin{array}{l}1894(53.5) \\
1649(46.5)\end{array}$ \\
\hline $\begin{array}{l}\text { My parent(s) /guardians communicate positively } \\
\text { 1. Yes } \\
\text { 2. No }\end{array}$ & $\begin{array}{l}2110(59.6) \\
1433(40.4)\end{array}$ \\
\hline $\begin{array}{l}\text { My parent(s) /guardians are willing to provide advice and } \\
\text { counseling } \\
\text { 1. Yes } \\
\text { 2. No }\end{array}$ & $\begin{array}{l}2140(60.4) \\
1403(39.6)\end{array}$ \\
\hline
\end{tabular}

Table 3: Parent communication among high school students in Addis Ababa.

\section{Parent communication}

As it is depicted in table 3,674(19.0\%) of the students reported that their parents communicated to them about sex, 748(21.1\%) about HIV transmission and prevention, 554(15.6\%) about STIs, 712(20.1\%) about pregnancy, and 1012(28.6\%) about changes occurring during adolescence.

In addition, 2140(60.4\%) of students reported that their parents were willing to provide advice and counseling, and 2110(59.6\%) of the respondents said that their parents communicate with them in a positive way.

Furthermore, 1894(53.5\%) of study participants reported that their parents talk to them about school.

\section{Parental monitoring and parenting styles}

Overall, 1332(37.6\%) of the respondents reported that their parents have clear rules and consequences, and 2100(59.3\%) of the respondents indicated their parents know their where about, 1470(41.5\%) know all their friends and $1760(49.7 \%)$ they need permission from parents to go anywhere (Table 4).

Furthermore, in relation to parental permissiveness 1424(40.2\%), $1466(41.4 \%)$, and 698(19.7\%) indicated that their parents allow them to stay at friends' houses overnight if they want to, parents do not mind if they get a boyfriend/girlfriend, and parents think it is okay for teenagers to have sex respectively (Table 4 ).

Regarding, parenting style 1553(43.8\%) of participants perceived that their parents follow authoritarian parenting style, 926(26.1) authoritative parenting style, 615(17.4\%) permissive parenting style and 449(12.7\%) neglectful parenting style (Table 4).

\section{Sexual activity among high school students}

Table 5 depicts the sexual practice of students. A total of $723(20.4 \%)$ respondents ever had sex. Of these $574(79.4 \%)$ had had sexual intercourse in the 12 months preceding the survey and 262(45.6\%) had had two or more sexual partners; out of these 319(55.6\%) reported

\begin{tabular}{|c|c|}
\hline Variables & Number(\%) \\
\hline $\begin{array}{l}\text { My parent(s) /guardians have clear rules and consequences } \\
\text { 1. Yes } \\
\text { 2. No }\end{array}$ & $\begin{array}{l}1332(37.6) \\
2211(62.4)\end{array}$ \\
\hline $\begin{array}{l}\text { My parent(s)/guardians know where I am if I am not at home } \\
\text { 1. Yes } \\
\text { 2. No }\end{array}$ & $\begin{array}{l}2100(59.3) \\
1443(40.7)\end{array}$ \\
\hline $\begin{array}{l}\text { My parent(s) /guardians know all my friends } \\
1 . \text { Yes } \\
2 \text {. No }\end{array}$ & $\begin{array}{l}\text { 1470(41.5) } \\
2073(58.5)\end{array}$ \\
\hline $\begin{array}{l}\text { I need permission from my parent(s)/guardians to go anywhere } \\
\text { 1. Yes } \\
\text { 2. No }\end{array}$ & $\begin{array}{l}1760(49.7) \\
1783(50.3)\end{array}$ \\
\hline $\begin{array}{l}\text { My parent(s)/guardians allow me to stay at friends' houses } \\
\text { overnight if I want to } \\
\text { 1. Yes } \\
\text { 2. No }\end{array}$ & $\begin{array}{l}\text { 1424(40.2) } \\
2119(59.8)\end{array}$ \\
\hline $\begin{array}{l}\text { My parent(s)/guardians do not mind if I get a boyfriend/ } \\
\text { girlfriend } \\
\text { 1. Yes } \\
\text { 2. No }\end{array}$ & $\begin{array}{l}1466(41.4) \\
2077(58.6)\end{array}$ \\
\hline $\begin{array}{l}\text { My parent(s)/guardians think it is okay for teenagers to have } \\
\text { sex } \\
\text { 1. Yes } \\
\text { 2. No }\end{array}$ & $\begin{array}{l}\text { 698(19.7) } \\
2845(80.30\end{array}$ \\
\hline $\begin{array}{ll}\text { Parenting Style } \\
\text { 1. } & \text { Authoritarian } \\
\text { 2. } & \text { Authoritative } \\
\text { 3. } & \text { Permissive } \\
\text { 4. } & \text { Neglectful }\end{array}$ & $\begin{array}{l}1553(43.8) \\
926(26.1) \\
615(17.4) \\
449(12.7)\end{array}$ \\
\hline
\end{tabular}

Table 4: Parental monitoring and parenting style among high school students in Addis Ababa. 


\begin{tabular}{|l|c|}
\hline Sexual practice & No(\%) \\
\hline $\begin{array}{l}\text { Ever had sex } \\
\text { Yes }\end{array}$ & $723(20.4)$ \\
No & $2820(79.6)$ \\
\hline $\begin{array}{l}\text { Age at first coital debut } \\
\text { Below 16 years }\end{array}$ & $331(45.8)$ \\
\hline 16 and above years & $392(54.2)$ \\
\hline Had sex past 12 months & \\
Yes & $574(79.4)$ \\
No & $149(20.6)$ \\
\hline Number of partner/s past 12 months sex & \\
One & $312(54.4)$ \\
2 or more & $262(45.6)$ \\
\hline Consistent Condom use in the past 12 months sex & \\
Yes & $255(44.4)$ \\
No & $319(55.6)$ \\
\hline Risky sexual behavior & \\
Yes & $377(10.6)$ \\
\hline No & $3166(89.4)$ \\
\hline
\end{tabular}

Table 5: Sexual activity among high school students in Addis Ababa.

\begin{tabular}{|c|c|c|c|c|}
\hline \multirow[t]{2}{*}{ Sources of effect } & \multicolumn{2}{|c|}{$\begin{array}{c}\text { Number (\%) } \\
\text { Sexual activity }\end{array}$} & \multirow[t]{2}{*}{$\begin{array}{l}\text { Unadjusted OR } \\
(95 \% \mathrm{Cl})\end{array}$} & \multirow[t]{2}{*}{$\begin{array}{l}\text { Adjusted } \\
\text { OR }(95 \% \mathrm{CI})\end{array}$} \\
\hline & Yes & No & & \\
\hline $\begin{array}{l}\text { Living with } \\
\text { Both parents } \\
\text { Other arrangements }\end{array}$ & $\begin{array}{l}123 \\
254\end{array}$ & $\begin{array}{l}1841 \\
1325\end{array}$ & $\begin{array}{c}0.35(0.12-0.76) \\
1.00\end{array}$ & $\begin{array}{l}0.48(0.21-0.83) \\
1.00\end{array}$ \\
\hline $\begin{array}{l}\text { Parental connectedness } \\
\text { Yes } \\
\text { No }\end{array}$ & $\begin{array}{l}132 \\
245\end{array}$ & $\begin{array}{l}1658 \\
1508\end{array}$ & $\begin{array}{c}0.49(0.22-0.89) \\
1.00\end{array}$ & $\begin{array}{c}0.51(0.22-0.96) \\
1.00\end{array}$ \\
\hline $\begin{array}{l}\text { Parenting style } \\
\text { Authoritarian } \\
\text { Authoritative } \\
\text { Permissive } \\
\text { Neglectful }\end{array}$ & $\begin{array}{l}102 \\
68 \\
94 \\
309\end{array}$ & $\begin{array}{l}1451 \\
858 \\
521\end{array}$ & $\begin{array}{c}0.21(0.17-0.82) \\
0.23(0.18-0.89) \\
0.52(0.39-1.34) \\
1.00\end{array}$ & $\begin{array}{c}0.38(0.23-0.86) \\
0.41(0.24-0.93) \\
--- \\
1.00\end{array}$ \\
\hline $\begin{array}{l}\text { Parent Communication } \\
\text { Yes } \\
\text { No } \\
\end{array}$ & $\begin{array}{l}63 \\
314\end{array}$ & $\begin{array}{l}760 \\
2406\end{array}$ & $\begin{array}{l}0.63(0.29-0.91) \\
1.00\end{array}$ & $\begin{array}{c}0.56(0.31-0.94) \\
1.00\end{array}$ \\
\hline $\begin{array}{l}\text { Parental Monitoring } \\
\text { Yes } \\
\text { No }\end{array}$ & $\begin{array}{l}124 \\
253\end{array}$ & $\begin{array}{l}1659 \\
1507\end{array}$ & $\begin{array}{c}0.44(0.24-0.86) \\
1.00\end{array}$ & $\begin{array}{c}0.52(0.32-0.92) \\
1.00\end{array}$ \\
\hline
\end{tabular}

Table 6: Parental practices and styles and risky sexual behavior Among High School students in Addis Ababa.

inconsistent condom use. Moreover, 331(45.8\%) of those who ever had sex started coital debut before the age of 16 .

\section{Parental practices and styles and risky sexual behavior}

The parental correlates of risky sexual behavior are shown in Table 6. Respondents who live with both parents [AOR=0.48 (95\%CI: 0.21 $0.83)]$ were less likely to experience risky sexual behavior. Parental connectedness was protective from risky sexual behaviors $[\mathrm{AOR}=$ 0.51(95\%CI: 0.22-0.96)].

There was significant association between parenting style and risky sexual behavior. Students from authoritarian and authoritative parents were more likely to have safe sexual practices $[\mathrm{AOR}=0.38(95 \% \mathrm{CI}$ : $0.23-0.86)]$ and $[\mathrm{AOR}=0.41(95 \% \mathrm{CI}: 0.24-0.93)]$ respectively.

Students who perceived their parents communicated to them about sexual issues were less likely to have sexual risk behavior $[\mathrm{AOR}=0.56$ (95\%CI: 0.31- 0.94)] than their counterparts. Parental monitoring was significantly associated with risky sexual behavior. Consistent supervision and monitoring of children were protective from risky sexual behavior $[\mathrm{AOR}=0.52(95 \% \mathrm{CI}: 0.32$ - 0.92)].

\section{Discussion}

This study intended to assess the effect of different parenting styles and parenting practices on the sexual behavior of adolescents. About $723(20.4 \%)$ students reported ever having sexual intercourse and nearly three-quarter of those who initiated sex were involved in risky sexual practices. The study showed that positive parenting practices had association with safe sexual behavior.

The study used large sample size and an extensive sampling procedure to maximize the representation of the sample to similar population. However, there are some potential limitations. A crosssectional design was used in this study to assess the effects of parenting practices on sexual risk-taking behaviors. Although such studies can provide useful data they are not optimal for illuminating processes by which these behaviors are linked. In addition, parenting practices have been assessed only from the students' perspective.

This study showed that $55.4 \%$ of students live with parents. Concurring with evidences from previous studies students living with both parents were less likely to be involved in risky sexual behavior [1619]. This could be explained that students living with both parents may be more secured and parents may also be available and have more time to support, show love, communicate and monitor their children Thus, pre marriage and marriage counseling should be in place and special attention should be given to interventions that aim the development of positive family life.

Nearly half of students reported that they have good connections with their parents. In line with research evidences elsewhere and diverging from the Zambian study the findings of this study shown that parent child connectedness is protective against risky sexual behavior [20-26]. This difference could be explained by cultural differences. Parental warmth, love and support increase the quality of parent child relationship and communication between parents and children. Thus, interventions that strengthen this bond need priority attention.

Communication about sexuality issues within the family appears to be important [27-29]. However, it was only one fifth of the students who communicated about sexual matters with their parents. Our study evidenced the association of parent child communication and sexual risk taking behavior. Respondents who reported communication with their parents about sexual issues were less involved in risky sexual behavior. Thus, parents should be helped to develop effective communication skills on sexual matters. In addition, the extent of communication, the content of the information that is communicated; and the timing of the communication should be given consideration.

Half of the students in this study indicated that their parents know their whereabouts and their friends. Parental monitoring appears to be consistently associated to a lower likelihood of risky sexual behavior in previous studies -[30-34]. Our study is in agreement with these evidences. This entails that family level interventions are vital with parental monitoring playing a substantial role.

Parenting styles are important to consider when examining parentadolescent relationships. The substantial influence of parenting style on adolescent development is clear. Previous researches exhibited the protective effect of authoritative parenting style from risky sexual behavior [35]. However, this study showed adolescents raised in authoritarian and authoritative households had higher protective and fewer risk behaviors than adolescents from permissive families. The data presented here affirms the importance of authoritarian and authoritative parenting style in shielding children from risky sexual practices. 
Citation: Cherie A, Berhanie Y (2015) Assessment of Parenting Practices and Styles and Adolescent Sexual Behavior among High School Adolescents in Addis Ababa, Ethiopia. J AIDS Clin Res 6: 424. doi:10.4172/2155-6113.1000424

\section{Conclusion}

Parenting styles and practices have paramount influence on the sexual behavior of adolescents. Children raised in authoritative and authoritarian home, live with both parents, feel connected with parents, communicated with parents about sexuality and monitored and supervised by parents are less involved in sexual risk behavior. Thus, training parents on how to nurture their children have supreme importance in risk behavior reduction. Interventions targeting the current and would be parents about proper parenting practices, skills and styles should be given special considerations.

\section{Acknowledgements}

We are grateful to John Hopkins University for funding the study. We are thankful to the study participants for their willingness to share their ideas and thoughts.

\section{References}

1. World Health Organization (2010) Strengthening the health sector response to adolescent health and development.

2. UNFPA (2012) Adolescent pregnancy. A review of the evidence. New York

3. World Health Organization (2005) Unsafe Abortion: Global and regional estimates of the incidence of unsafe abortion and associated mortality in 2003. Geneva, World Health Organization.

4. Dehne KL, Riedner G (2001) Sexually transmitted infections among adolescents: the need for adequate health services. Reprod Health Matters 9: 170-183.

5. Lewis DA, Latif AS, Ndowa F (2007) WHO global strategy for the prevention and control of sexually transmitted infections: time for action. Sex Transm Infect 83: 508-509.

6. WHO (2001) Global prevalence and Incidence of Selected Curable Sexually Transmitted Infections: Overview and Estimates.

7. Centers for Disease Control and Prevention (2008a) Sexually transmitted disease surveillance 2007.

8. UNAIDS (2014) Epidemiological slides - GAP report.

9. Crosby RA, Diclemente RJ, Wingood GM, Cobb BK, Harrington K, et al. (2002) Condom use and correlates of African American adolescent females' infrequent communication with sex partners about preventing sexually transmitted diseases and pregnancy. Health Educ Behav 29: 219-231.

10. Dittus P, Jaccard J, Gordon V (2000) Direct and non-direct communication of maternal beliefs to adolescents: adolescent motivations for premarital sexual activity. Journal of Applied Social Psychology 29: 37-55.

11. Downing J, Jones L, Bates G, Sumnall H, Bellis MA (2011) A systematic review of parent and family-based intervention effectiveness on sexual outcomes in young people Health Education Research 26: 808833.

12. Baumrind $D$ (1991) The influence of parenting style on adolescent competence and substance use. J Early Adolescence 11: 56-95.

13. Jackson C, Henriksen L, Foshee VA (1998) The Authoritative Parenting Index: predicting health risk behaviors among children and adolescents. Health Educ Behav 25: 319-333.

14. Amsale Cherie, Yemane Berhanie (2012) Peer Pressure Is the Prime Driver of Risky Sexual Behaviors among School Adolescents in Addis Ababa, Ethiopia. World Journal of AIDS 2: 159-164.

15. CDC (2010) Youth Risk Behavior Surveillance-United States, 2009. MMWR 59: $1-142$.

16. Babalola S, Tambashe BO, Vondrasek C (2005) Parental factors and sexual risk taking among young people in Côte-d'Ivoire. Afr J Reprod Health 9:49-65.

17. Biddlecom A, Awusabo-Asare K, Bankole A (2009) Role of parents in adolescent sexual activity and contraceptive use in four African countries. Int Perspect Sex Reprod Health 35: 72-81.

18. Karim AM, Magnani RJ, Morgan GT, Bond KC (2003) Reproductive health risk and protective factors among unmarried youth in Ghana. Int Fam Plan Perspect 29: 14-24.
19. Amsale Cherie, Yemane Berhane (2012) Oral and anal sex practices among high school youth in Addis Ababa, Ethiopia. BMC Public Health 12: 5.

20. Magnani RJ, Karim AM, Weiss LA, Bond KC, Lemba M, et al. (2002) Reproductive health risk and protective factors among youth in Lusaka, Zambia. J Adolesc Health 30: 76-86.

21. Longmore MA, Eng AL, Giordano PC, Manning WD (2009) Parenting and adolescents' sexual initiation. J Marriage Fam 71: 969-982.

22. Miller BC (2002) Family influences on adolescent sexual and contraceptive behavior. J Sex Res Health 39: 22-26.

23. Markham CM, Lormand D, Gloppen KM, Peskin MF, Flores B, et al. (2010) Connectedness as a predictor of sexual and reproductive health outcomes for youth. J Adolesc Health 46: 23-41.

24. Barber BK, Schluterman JM (2008) Connectedness in the lives of children and adolescents: A call for greater conceptual clarity. J Adolesc Health 43: 209-216.

25. Kayembe KP, Mapatano MA, Busangu FA, Nyandwe KJ, Mashinda KD, et al. (2008) Correlates of ever had sex and of recent sex among teenagers and young unmarried adults in the democratic republic of Congo. AIDS Behav 12 585-593.

26. Tsala Dimbuene Z, Kuate Defo B (2012) Family environment and premarita intercourse in Bandjoun (West Cameroon). Arch Sex Behav 41: 351-361.

27. Ngom P, Magadi MA, Owuor T (2003) Parental presence and adolescent reproductive health among the Nairobi urban poor. J Adolesc Health 33: 369 377.

28. Kumi-Kyereme A, Awusabo-Asare K, Biddlecom A, Tanle A (2007) Infuence of social connectedness, communication and monitoring on adolescent sexual activity in Ghana. Afr J Reprod Health 11: 133-149.

29. Bastien S, Kajula LJ, Muhwezi WW (2011) A review of studies of parent-child communication about sexuality and HIVIAIDS in sub-Saharan Africa. Reprod Health 8: 25

30. Kawai K, Kaaya SF, Kajula L, Mbwambo J, Kilonzo GP, et al. (2008) Parents and teachers' communication about HIV and sex in relation to the timing of sexual initiation among young adolescents in Tanzania. Scand J Public Healt 36: 879-888.

31. Dishion TJ, McMahon RJ (1998) Parental monitoring and the prevention of child and adolescent problem behavior: a conceptual and empirical formulation. Clin Child Fam Psychol Rev 1: 61-75.

32. Li X, Stanton B, Feigelman S (2000) Impact of perceived parental monitoring on adolescent risk behavior over 4 years. J Adolesc Health 27: 49-56.

33. Sieverding JA, Adler N, Witt S, Ellen J (2005) The influence of parental monitoring on adolescent sexual initiation. Arch Pediatr Adolesc Med 159: 724 729.

34. Joyce Wamoyi, Angela Fenwick, Mark Urassa, Basia Zaba, William Stones (2011) Parental control and monitoring of young people's sexual behavior in rural North-Western Tanzania: Implications for sexual and reproductive health interventions. BMC Public Health 11: 106.

35. Huebner AJ, Howell LW (2003) Examining the relationship between adolescent sexual risk-taking and perceptions of monitoring, communication, and parenting styles. Journal of Adolescent Health 33: 71-78. 